\title{
The equine cervix
}

\author{
Terttu Katila \\ Faculty of Veterinary Medicine, University of Helsinki, Saarentaus, Finland
}

\begin{abstract}
Summary
The cervix of the mare has not been studied much, although its important role in reproduction has been recognized. The cervix is one of the sphincters of the female reproductive tract. Prevention of uterine contamination from the caudal tract is vital for the uterine health and for a successful pregnancy; the cervix has to be tightly closed to seal the uterus. On the other hand, during estrus the cervix has to soften and dilate. The open cervix allows the entrance of sperm into the uterus, but also facilitates the elimination of excessive sperm and inflammatory by-products after insemination. Failure to open adequately is a common cause for insufficient uterine drainage in maiden mares. During parturition, the cervix has to ripen and dilate enormously to allow the delivery of the foal. Involution of the cervix proceeds rapidly, and after the foal heat ovulation the cervix should close in a normal fashion. Cervical lacerations and adhesions are pathological consequences of foaling. The equine cervix has a simple structure and can therefore be manually dilated any time. The tunica mucosa is branched to primary, secondary and tertiary folds. The simple columnar epithelium consists of two types of cells: non-ciliated goblet-like cells which produce mucin and kinociliated cells. The examination methods are transrectal palpation, transrectal ultrasonography, transvaginal palpation and vaginoscopy. Based on the examination findings the cervix has been divided into four categories indicating different degrees of steroid hormone influence and subsequently the stage of the estrous cycle. Developmental abnormalities of the mare's cervix are rare, but some have been reported. Cervical lacerations and adhesions result from parturition. Failure of cervical dilation may be congenital or required. Fibrosis is most commonly encountered in old maiden mares. Failure to open results in accumulation of intrauterine fluid because of deficient drainage and leads subsequently to uterine inflammation and infection and lowered fertility. This paper is a review of the literature published about the equine cervix including anatomy, histology, physiology, examination, pathology and cervical drainage.
\end{abstract}

Keywords: Cervix, horse, mare, reproduction

\section{Die Zervix des Pferdes}

Obwohl die Zervix der Stute eine große Rolle in der Reproduktion spielt, ist sie wenig erforscht. Sie ist einer der Sphinkteren des weiblichen Genitaltraktes. Die Prävention einer uterinen Kontamination aus dem kaudalen Trakt ist essentiell für die uterine Gesundheit und eine erfolgreiche Trächtigkeit; die Zervix hat fest geschlossen zu sein, um den Uterus abzudichten. Andererseits muss die Zervix während des Östrus nachgeben und dilatieren. Die geöffnete Zervix erlaubt den Eintritt von Sperma in den Uterus, erleichtert aber auch die Elimination von überschüssigen Spermien und Entzündungsprodukten nach der Insemination. Entsprechend ist eine mangelhafte Öffnung der Zervix ein häufiger Grund für eine ungenügende uterine Drainage bei Maidenstuten. Während der Geburt muss sich die Zervix voll entwickeln und enorm dilatieren. Die Involution der Zervix vollzieht sich sehr schnell, nach der Ovulation in der Fohlenrosse sollte die Zervix in normaler Art und Weise geschlossen sein. Zervikale Risswunden und Adhäsionen sind pathologische Folgen des Partus. Die equine Zervix hat eine einfache Struktur und kann daher zu jeder Zeit manuell gedehnt werden. Die Tunica mucosa ist in primäre, sekundäre und tertiäre Falten verzweigt. Das einfache zylindrische Epithel besteht aus zwei Zellarten: nicht-zilierte Becherzell-artige Zellen, die Muzin produzieren, und Zellen mit Kinozilien. Als Untersuchungsmethoden stehen die transrektale Palpation, die transrektale Sonographie und die Vaginoskopie zur Verfügung. Basierend auf den Untersuchungsergebnissen lässt sich die Zervix in vier Kategorien einteilen, die über den Grad des Steroidhormoneinflusses Auskunft geben, und damit über den Zyklusstand. Missbildungen der Stutenzervix sind selten, aber von einigen wird in der Literatur berichtet. Zervikale Risswunden und Adhäsionen sind Folgen des Geburtsvorganges. Mangelhafte zervikale Dilatationen sind angeboren oder erworden. Fibrosierungen werden am häufigsten bei älteren Maidenstuten beobachtet. Die mangelhafte Öffnung der Zervix resultiert in einer Akkumulation intrauteriner Flüssigkeit als Folge einer defizienten Drainage. Sie führt zur uterinen Entzündung und Infektion und zur verminderten Fertilität. Ziel dieser Arbeit ist es, eine Literaturübersicht über die Anatomie, Histologie, Physiologie, Untersuchung, Pathologie und Drainage der Zervix zu geben.

Schlüsselwörter: Zervix, Pferd, Stute, Reproduktion

\section{Anatomy and histology}

The equine cervix is a relatively simple cylindrical structure with no transverse rings. The normal length is 5 to $7 \mathrm{~cm}$ and width 3 to $4 \mathrm{~cm}$ (Tibary 2011). The longitudinal endometrial folds continue to the cervix facilitating uterine drainage. The cervix can be digitally dilated at any stage of the reproductive cycle. The caudal portion protrudes into the vagina as portio vaginalis which can be visualized in a vaginoscopic examination. The folds continue onto the vaginal floor as ventral frenula. A dorsal frenulum continuing dorsally from the cervix is visible against the cranial wall of the vagina (Ginther 1992).
The smooth muscle is formed by two layers: an inner circular and an outer longitudinal layer, which are continuous with the muscle layers of the vagina and uterus (Sertich $2011)$. A thickened circular muscle layer forms the body of the portio vaginalis.

The cervical canal of mares is lined with a simple columnar epithelium. The tunica mucosa is branched to primary, secondary and tertiary folds. Two types of alternately arranged epithelial cells are differentiated: non-ciliated gobletlike cells and kinociliated cells (Huchzermeyer et al.2005). Goblet-like cells produce mucin and the kinocilia support 
the flow of mucus caudally. During estrus, mucus acts as a lubricant and during pregnancy as a sealant.

The glandless lamina propria mucosae contains veins, venules, arteries, and arterioles. Huchzermeyer et al. (2005) called this a venous plexus also in mares, similarly to the canine cervix. The authors suggested that a strong vascularization ensures rapid immunological reaction to bacteria and may support the occlusion of the cervical canal. The thick circular muscular layer rich in elastic fibers expands and contracts the cervix.

Large numbers of adrenergic- and peptidergic-immunoreactive nerve fibres have been identified in the myocervix of mares. This high density of innervation indicates a role in cervical closure during diestrus and pregnancy, and in relaxation during estrus and parturition (Bae et al. 2001).

Eosinophilic granulocytes and mast cells have been found in the lamina propria in diestrous mares. The density of both cell types was highest in the external orifice suggesting that eosinophils might be a part of the local cellular immune system (Wehrend et al. 2005).

\section{Physiology}

Changes in the cervix are primarily regulated by progesterone and estrogens: progesterone closes and tightens whereas estrogen opens and dilates the cervix. Due to the great individual variation among mares, estradiol- 17 and progesterone levels were not very well correlated with the cervical state. However, the estradiol-17: progesterone ratio was more informative: estrus $>5$ and diestrus $<5$ (Waelchli et al. 1994).

Cytosolic estrogen and progesterone receptors have been detected in the mare cervix, although the numbers were lower in the cervix than in the uterus (Re et al. 1995). In ewes, estrogen and progesterone receptors increased from epithelium to deep stroma and from the uterine part to the vaginal part of the cervix (Breeveld-Dwarkasing et al.2002).

It has been shown in many species that the cervix is immunologically competent producing antibodies in response to antigens. Immunoglobulins IgA and IgG are present in the cervical mucus and tissues. Antibodies to spermatozoa have been demonstrated in cervical mucus of women. In rabbits, the ectocervix became edematous and polymorphonuclear cells (PMN) invaded the portio vaginalis within 30 min of insemination of whole semen including spermatozoa (Tyler 1977). In contrast in ewes, the presence of spermatozoa in the cervix and vagina had no effect on the migration of PMNs; PMNs in the cervix represent drainage from the uterus (Mattner 1969). The reaction of the equine cervix to spermatozoa has not been studied.

Neutrophils are encountered in cervical biopsies and cytological smears of normal healthy mares (Aguilar et al.2006). Swabs obtained from the cervix grew in $33 \%$ of the cultures the same bacteria as vaginal swabs, and $46 \%$ of cervical cultures yielded the same bacteria as uterine cultures (Newcombe 1978). This shows that some bacterial growth and neutrophils in the cervical canal are normal findings. It also shows that guarded culture instruments are necessary to differentiate between uterine and cervical bacterial growth.

\section{Examination}

The examination methods are transrectal palpation, transrectal ultrasonography, transvaginal palpation and vaginoscopy. Transrectal palpation is done routinely every time when a mare is examined. Ultrasonography has only recently been employed in the examination of the cervix. Transvaginal examinations require cleansing of the perineal area and are therefore not done every single time. However, they provide useful information in cases where e.g. the ovarian, uterine, and/or cervical findings are controversial.

The cervix is found about the middle of the forearm. The floor of the pelvis is swept with the palm side of the fingers back and forth until the cervix has been evaluated for relaxation (length, width, consistency). Greenhoff and Kenney (1975) classify the cervix to four categories. An X cervix is long, thumb-like, up to $2 \mathrm{~cm}$ in diameter and firm. This reflects progesterone dominance: diestrus or pregnancy. The $\mathrm{C}$ cervix mirrors an early effect of estrogen. It is still relatively tight, but some circumferential edema (softening) can be palpated. The $B$ cervix shows continued effects of estrogen; the diameter is larger, the cervix is flatter and shorter and feels relaxed. In an A cervix the relaxation is complete, and the cervix is hardly palpable.

In a vaginoscopical examination we can see the portio vaginalis, its color, degree of edema and relaxation. In addition, possible adhesions and secretions can be detected. The $X$ cervix is small, dry, yellowish pink to gray, and lies in the center of the vaginal vault with long ventral frenula. The $\mathrm{C}$ cervix is pink, slightly swollen and a little bit open. It is still in the center of the field or has dropped slightly. The B cervix is deep pink, the orifice is larger and some clear mucus can be seen. It has dropped below the center and the folds are limp and edematous. The A cervix lies on the vaginal floor; the cervical folds are flaccid and edematous and sometimes hard to discern. The membranes are deep pink and shiny due to abundant mucus (Greenhoff et al.1975).

The degree of cervical relaxation can also be evaluated by passing one or more fingers into the cervical canal. $X$ cervix is so tight that not even one finger can be introduced. In addition, the external os protrudes into the vagina. One finger fits into the $C$ cervix and two fingers into the $B$ cervix. The lumen of an A cervix readily admits three fingers or even the whole hand (Greenhoff et al.1975). At the same time, patency and possible adherences can be palpated.

The integrity of the cervical walls is evaluated digitally during diestrus. The forefinger is placed in the cervical canal and the left wall is palpated between the thumb and forefinger. Then the thumb is moved into the lumen and the right wall is palpated between the thumb and forefinger (Pollock et al.2011).

Day et al. (1995) evaluated the entire length of the cervix in a longitudinal image using transrectal ultrasonography. The appearance of the cervix was scored in the following manner: 1) mucosal and muscular regions are narrow, 2) muco- 
sal and muscular regions are uniform with defined borders, 3) musculature $(M)$ is less echoic anterior to the external os appearing more echoic with defined boarders, 4) musculature is uniformly hypoechoic near the mucosa, and 5) upper and lower muscular regions appear homogenously hypoechoic. Also the incidence of the appearance of slightly echoic mucosal region was observed. Their scores of 1 and 2 correspond to the $X$ cervix of Greenhoff and Kenney and were characterized by echoic and thin $M$, where mucosalmuscular junction was distinguishable and the cervical canal showed parallel echoic white lines. Score 3 (C cervix) was assigned when mucosal-muscular junction was distinguishable only near external os and the canal was smaller near external os and parallel lines were more disperse if present. Score 4 (B cervix) was used for $M$ which was thick and echoic only near serosal borders. The canal showed faint lines, and mucosa exhibited greater echogenicity than $M$. In score 5 cervix (A), $M$ was homogenously hypoechoic and in the canal faint lines may be present, homogenous in appearance with M (Day et al. 1995).

Campbell and Bliss (2010) measured the diameter of the cervix in cross section and found the width to correlate best with relaxation increasing linearly towards ovulation (Campbell et al. 2010).

\section{Pathological conditions}

Developmental abnormalities of the mare's cervix are rare, but have been reported. Mares with chromosomal abnormalities usually have an underdeveloped, open cervix because of a lack of hormonal stimulation (Hurtgen 2011). Complete absence of cervix, cervical hypoplasia (Allen 1981), cervical hyperplasia (Riera et al. 1989) and congenital cervical incompetency (Blanchard et al.1982) have been reported. Incomplete fusion of Müllerian ducts may result in complete or partial duplication of the cervix; cervical canal can also end blindly. A mare may have a double cervix, each cervix leading to one uterine horn; these mares are sterile, because the embryonic mobility is restricted (Hurtgen 2011 ). Cervical varices with thrombosis were diagnosed in a virgin Peruvian Paso mare (Foster et al. 1997).

Cervical lacerations arise during the second stage of labour. Often the parturition has been spontaneous, but of course, injuries can also be caused by assistance in dystocia, particularly fetotomy. If the fetus passes through the birth canal rapidly before the cervix is fully dilated, there is a danger for the cervix to tear. Lacerations can affect only the muscular layer or all three layers, but both interfere with proper cervical function. The epithelium can form transluminal adhesions which prevent normal cervical relaxation and uterine drainage. A lacerated piece of portio vaginalis can also adhere to the vaginal epithelium. Irritating substances infused into the uterus can cause severe inflammation and transluminal and - vaginal adhesions (Sertich 2011).

Severe cervical adhesions are rarely treatable. Manual disruption of adhesions and subsequent daily steroid ointment applications are the treatment options. If the portio vaginalis is adhered to the vaginal floor, it may be dissected free and equipped with retraction sutures to allow daily manipulation to prevent the re-formation of adhesions. Lacerations are corrected by surgical closure (Sertich 2011).

\section{Cervical drainage}

Failure of cervical dilation may be congenital or acquired. Congenital extreme tortuosity of the cervix is associated with a failure to relax during estrus. These mares tend to accumulate fluid in the uterus. If untreated, the condition may lead to pyometra. Cervical adhesions have been acquired during parturition.

Fibrosis of the cervix due to the loss of elasticity which probably increases with aging is most commonly encountered in old maiden mares (Tibary 2011) but also young maiden mares may exhibit inadequate cervical relaxation and patency during estrus.

Palpation of a cervix, the lumen of which is barely accessible by one finger, and the presence of intrauterine fluid suggest a mare with cervical problems. Digital dilation to a patency of 1 to 2 fingers is the preferred treatment (Pycock 1994). In difficult cases, PGE 1 (misoprostol) can be applied in the cervical canal (Nie et al.2003).

The important role of the cervix in uterine drainage is well known (LeBlanc et al.1994). Occlusion of the cervix with intracervical catheters for $25 \mathrm{~h}$ after insemination resulted in accumulation of intrauterine fluid and cytokines (IL-6 and TNF- ), and increased numbers of PMNs (Liepina et al.2010c and b). The differences between the treatment (catheters in the cervix) and control (no catheters) groups had disappeared by $48 \mathrm{~h}$, when the catheters had been removed (Liepina et al. 2010b).

An unexpected finding was an carry over effect, although there was an untreated cycle between the two treatment cycles. In control treatments during the 2 nd treatment cycle (occlusion of the cervix was the treatment during the 1st cycle), the PMN numbers were ten times higher than in the controls during the 1 st treatment. Pregnancy rates for all groups combined were $41.7 \%$ in the first treatment cycle and $16.7 \%$ in the second treatment cycle. Endometrial biopsies obtained in the cycle before the treatments started and after the end of the experiment did not show significant changes for inflammatory cells or fibrosis (Liepina et al.2010a). The reason for the increased inflammatory response is not known. For mare practice it is important to note that failure of the cervix to dilate in association with Al represents serious uterine challenge and may have negative consequences also in the future cycles.

\section{References}

Aguilar J., Hanks M., Shaw D. J., Else R. and Watson E. (2006) Importance of using guarded techniques for the preparation of endometrial cytology smears in mares. Theriogenology 66, 423-430

Allen E. A. (1981) A cervical anomaly in an arabian filly. Equine Vet. J. 13, 268-269

Bae S. E., Corcoran B. M. and Watson E. D. (2001) Immunohistochemical study of the distribution of adrenergic and peptidergic innervation in the equine uterus and the cervix. Reproduction 122, 275-282 
Blanchard T. L., Evans L. H., Kenney R. M., Hurtgen J. P. and Garcia M. C. (1982) Congenitally incompetent cervix in a mare. J. Am. Vet. Med. Ass. 181, 266

Breeveld-Dwarkasing V. N., de Boer-Brouwer M., Möstl E., Soede N. M., van der Weiden G. C., Taverne M. A. M. and van Dissel-Emiliani F. M. F. (2002) Immunohistochemical distribution of oestrogen and progesterone receptors and tissue concentrations of oestrogens in the cervix of non-pregnant cows. Reprod. Fertil. Dev. 14, 487-494

Campbell M. L. H. and Bliss A. J. (2010) A novel ultrasonographic method for measuring cervical relaxation at different stages of the estrous cycle in mares. Anim. Reprod. Sci. 121S, S84-85

Day W. E., Evans J. W., Vogelsang M. M. and Westhusin M. E. (1995) Characterization of the cervix in cycling mares using ultrasound. Mono 1, 519-526

Foster R. A., Gartley C. J. and Newman S. (1997) Varices with thrombosis in the cervix and uterus of a mare. Can.Vet.J. 38, 375-376

Ginther O. J. (1992) Reproductive biology of the mare. basic and applied aspects. 2nd ed. Equiservices, Wisconsin, USA

Greenhoff G. R. and Kenney R. M. (1975) Evaluation of reproductive status of nonpregnant mares. J. Am. Vet. Med. Ass. 167, 449458

Huchzermeyer S., Wehrend A. and Bostedt H. (2005) Histomorphology of the equine cervix. Anat. Hist. Embr. 34, 38-41

Hurtgen J. P. (2011) Abnormalities of cervical and vaginal development. In: McKinnon A. O., E. L. Squires, W. E. Vaala, D. D. Varner, eds.Equine reproduction. 2nd ed. Wiley-Blackwell, 2719. 2720

LeBlanc M. M., Neuwirth L., Asbury A. C., Tran T., Mauragis D. and Klapstein E. (1994) Scintigraphic measurement of uterine clearance in normal mares and mares with recurrent endometritis. Equine Vet. J. 26, 109-113

Liepina E. and Antane V. (2010a) Endometrial histological changes and pregnancy rates in mares with impaired uterine drainage. Proc. 29th Int. Sci. Conf. Animal Health. Food Hygiene, Jelgava, Latvia, 73-78

Liepina E., Antane V. and Rivera del Alamo M. M. (2010b) Intrauterine fluid secretion in mares after artificial insemination. Proc. 16th Int. Sci. Conf. "Research for rural development”, Jelgava, Latvia 2010, 12-16

Liepina E., Rivera del Alamo M. M., Reilas T. and Katila T. (2010c) IL6 and TNF- expression in uterine fluids of mares with induced delay in uterine clearance. Anim. Reprod. Sci. 121S, S107-108
Mattner P. E. (1969) Differential leucocytic responses to spermatozoa in the cervix and the uterus in ewes. J. Reprod. Fertil. 18, 297-303

Newcombe J. R. (1978) Comparison of the bacterial flora of three sites in the genital tract of the mare. Vet. Rec. 102, 169-170

Nie G. and Barnes A. (2003) Use of prostaglandin E1 to induce cervical relaxation in a maiden mare with post breeding endometritis. Equine Vet. Educ. 15, 172-174

Pollock J. P. and T. M. Russell (2011) Cervical surgery. In: McKinnon A. O., E. L. Squires, W. E. Vaala, D. D. Varner, eds. Equine reproduction. 2nd ed. Wiley-Blackwell, 2559-2563

Pycock J. F. (1994) A new approach to treatment of endometritis. Equine Vet. Educ. 6, 36-38

Re G., Badino P., Novelli A., Di Renzo G. F., Severino L., De Liguoro M. and Ferone M. R. (1995) Distribution of cytosolic oestrogen and progesterone receptors in the genital tract of the mare. Res. Vet. Sci. 59, 214-218

Riera F. L., Hinrichs K., Hunt P. R. and Kenney R. M. (1989) Cervical hyperplasia with prolapse in a mare. J. Am. Vet. Med. Ass. 195, 1393-1394

Sertich P. L. (2011) Cervix adhesions. In: McKinnon A. O., E. L. Squires, W. E. Vaala, D. D. Varner, eds. Equine reproduction. 2nd ed. Wiley-Blackwell, 2721-2723

Tibary A. (201 1) Failure to dilate. In: McKinnon A. O., E. L. Squires, W. E. Vaala, D. D. Varner, eds. Equine reproduction. 2nd ed. Wiley-Blackwell; p. 2724-2730

Tyler K. R. (1977) Histological changes in the cervix of the rabbit after coitus. J. Reprod. Fertil. 49, 341-345

Waelchli R. O., Känzig M., Döbeli M. and Rüsch P. (1994) Condition of the uterine cervix in relation to cycle stage, plasma progesterone and estradiol-17. Reprod. Dom. Anim. 29, 404-410

Wehrend A., Huchzermeyer S. and Bostedt H. (2005) Distribution of eosinophils and mast cells in the cervical tissue of non-gravid mares during dioestrus. Reprod. Dom. Anim. 40, 562-563

\section{Tenttu Katila}

Department of Production Animal Medicine

Faculty of Veterinary Medicine

University of Helsinki

Paroninkuja 20

04920 Saarentaus

Finland

terttu.katila@helsinki.fi 